\title{
ВОЕНН ЗЛОЧИНИ В СИСТЕМІ МІЖДНАРОДНОГО ГУМАНІТАРНОГО ТА МІЖНАРОДНОГО КРИМІНАЛЬНОГО ПРАВА
}

\author{
ПИЛИПЕНКО Володимир Пилипович - кандидат юридичних \\ наук, Заслужений юрист України, член Европейської комісії
} за демократію через право (2013-2017 рр.)

УДК 341.322.5

DOI 10.32782/LAW.UA.2021.3.25

\begin{abstract}
В статье исследуются видъ военнъих преступлений в международном праве. Особое внимание в статье уделяется анализу таких составов военных преступлениц, как серьезнъие нарушения Женевских конвениий 1949 г., совершаемъие во время международнъх вооруженньх конфбликтов; другие сервезнъие нарушения правил ведения международньх вооруженных конфблктов; серьезнъие нарушения Женевских конвениий 1949 г, совершаемъие во время немеждународных вооруженных конфблктов; другие сервезнъле нарушения правил ведения немеждународньхх вооруженных конбликтов. Особое внимание в статье уделяется анализу международного объгчного права относительно квалибикациии военных преступлений, совершенных во время международнъхх и немеждународнъих вооруженнъих конфликтов.

Ключевъе слова: военнъе преступления, международнъие уголовнъе трибуналь, Международный уголовнылй суд, вооруженныи конбликт международного характера, вооруженный конбликт немеждународного характера, Женевские конвениии, 1949 года, Дополнительнъий протокол 1 u Дополнительный протокол II к Женевским конвенциям и $р$.
\end{abstract}

Постановка проблеми

Історичний досвід XX ст. показує, що найжахливіші звірства і жорстокості відбувалися під час воєн і збройних конфліктів. Беззаперечною $є$ теза, що будь-які збройні конфлікти в сучасних умовах глобалізації створюють неабияку небезпеку для всього міжнародного співтовариства, не кажучи про цінність кожного Аюдського життя. Саме тому, врегулювання збройних конфліктів у правовій площині, i, перш за все, система імплікації в контексті різних типів конфліктів міжнародних гуманітарно-правових норм, спрямованих на порятунок цього людського життя, сьогодні мають нагальну необхідність у вдосконаленні, систематизації та приведенні у відповідність до викликів сучасності.

Наразі у світі нараховується майже чотири десятки збройних конфліктів та воєн, одна 3 яких триває в Україні. Кількість збройних конфліктів у світі від часів завершення Другої світової війни помітно зросла. Але якщо раніше це були міждержавні збройні конфлікти, наразі спостерігаємо переважно локальні конфлікти. Але часто в них бере участь інша держава, допомагаючи якійсь із сторін. Так, за даними Американського Центру всеохоплюючого миру (CSP), на початок 2017 року нараховувалось 36 збройних конфліктів. Безпосередню участь у них беруть 28 держав. 3 них майже половина (13 країн) мають затягнуті конфлікти - такі, що тривають понад десять років.

На жаль, проблематика цього дослідження сьогодні є актуальною й для України в контексті неоголошеної гібридної війни 3 боку РФ, наслідком якої стала тимчасова окупація АРК та м. Севастополь, окремих районів Донецької та Ауганської областей 
та продовженням збройного конфлікту на Сході України.

У зв’язку із заснуванням в 1990-х рр. міжнародних кріимнальних трибуналів під егідою ООН, а саме - Міжнародного трибуналу по колишній Югославії (далі - МКТКЮ) та Міжнародного трибуналу по Руанді (далі - МКТР), а також у зв’язку з прийняттям в 1998 р. Римського статуту Міжнародного кримінального суду (далі - МКС), у вітчизняній науці міжнародного права спостерігається різке підвищення інтересу до питань кримінальної відповідальності за порушення норм МГП, i, відповідно, до міжнародного кримінального права, яке криміналізує такі порушення.

Метою цієї статті є здійснити комплексний правовий аналіз воєнних злочинів, як серйозних порушень Женевських конвенцій, 1949 року та Додаткових протоколів до них, 1977 року в контексті міжнародного гуманітарного та міжнародного кримінального права.

\section{Аналіз останніх досліджень і публікацій}

Воєнні злочини неодноразово ставали предметом вивчення фахівців у галузі міжнародного і кримінального права як в Україні, так і в інших державах. Так, питанням кримінальної відповідальності за воєнні злочини займались такі вітчизяні та зарубіжні вчені, як А.Х. Абашидзе, В.Ф. Антипенко, Аль-Захарна Саліма, В.А. Базов, Ю.Г. Барсегов, В.А. Батирь, І.П. Бліщенко, М.В. Буроменський, В.Г. Буткевич, Н.В. Дрьоміна, С.О. Загороднюк, Н.А. Зелінська, А.В. Картавцев, Ю.М. Колосов, І.О. Колотуха, Н.І. Костенко, В.М. Аисик, I.I. Аукашук, А.С. Мацко, Н.Г. Михайлов, Ф.І. Полторак, М.Ю. Рагінський, С.А. Раджабов, В.М. Репецький, В.П. Попович, В.Х. Ярмакі та багато інших вчених.

\section{Виклад основного матеріалу \\ До початку XXI ст. в міжнародному праві сформувалася цілісна система джерел, що визначають правила (закони і звичаї) ведення збройних конфліктів. Основні}

ідеї щодо необхідності регламентації воєнних дій знайшли законодавче закріплення в міжнародно-правових актах на стику XIX-XX ст. (Гаазькі конвенції та відповідні Положення до них). Однак основи створення сучасної системи права ведення воєнних дій пов’язані з діяльністю та рішеннями Міжнародних воєнних трибуналів, створених за підсумками Другої світової війни, - Нюрнберзького і Токійського. Міжнародне співтовариство незмінно стикалися із злочинами, які несла в собі війна, однак приймало їх швидше як даність, як неминучу жертву на шляху до перемоги або поразки. Аналізуючи це питання, професор Н.A. Зелінська підкреслює, що «історія свідчить про те, що спроба запровадження міжнародного кримінального суду після Першої світової війни була відкинута саме тому, що суперечила міжнародній практиці: особи, винні в ініціюванні та веденні агресивної війни, ніколи не піддавалися кримінальним санкціям» [4, с. 179]. Разом з тим дві світові війни ХХ століття продемонстрували світові діяння небаченого до цього масштабу i цинізму, що зумовило зміну колишнього ставлення до злочинних діянь, які вчиняються в ході збройних конфліктів.

1945 рік став відправною точкою принципово нової політики міжнародного співтовариства 3 питань міжнародного кримінального права. $\mathrm{y}$ цей період міжнародна спільнота обрала істотно новий підхід до побудови міжнародного спілкування, іменований «правом на мир», відмовившись від концепції «права на війну». Перший крок у напрямку покарання індивідів за злочини відповідно до міжнародного права був зроблений 8 серпня 1945 року, коли чотири союзні держави: СРСР, США, Великобританія i Франція - підписали Лондонську угоду «Про судове переслідування і покарання головних воєнних злочинців європейських держав «осі», додатком до якої був Статут Міжнародного воєнного трибуналу [23]. Стаття 6 Статуту визначала категорії злочинів, за вчинення яких Трибунал мав право судити і карати будь-яких осіб або групи осіб. Такими категоріями злочинів 
були воєнні злочини, злочини проти миру і безпеки та злочини проти людяності.

Женевські конвенції 1949 року, у яких було кодифіковано МГП після Другої світової війни, містять перший в історії докладний перелік воєнних злочинів. Кожна $з$ чотирьох Женевських конвенцій: «Про поліпшення долі поранених i хворих у чинних арміях» [15] (I Женевська конвенція), «Про поліпшення долі поранених, хворих та осіб, які зазнали корабельної аварії, зі складу збройних сил на морі» [16] (II Женевська конвенція), «Про поводження 3 військовополоненими» [3] (III Женевська конвенція), «Про захист цивільного населення під час війни» [14] (IV Женевська конвенція) - містить власний перелік «серйозних порушень» правил і засобів ведення воєнних дій, які на сьогодні у міжнародному праві однозначно розцінюються як воєнні злочини.

Щодо ролі Женевських конвенцій 1949 р. у визначенні воєнних злочинів, В.Ю. Калугін справедливозауважив, що хоча безпосередньо у їх тексті і не вживається вираз «воєнні злочини», коли йдеться про «серйозні порушення» їх положень, то не підлягає сумніву, що маються на увазі саме воєнні злочини. За їх вчинення передбачається особиста відповідальність, так само як за порушення законів і звичаїв війни. «Ця термінологічна неясність пояснюється прагненням підкреслити зобов’язання договірних держав запобігати актам, що заборонені, і карати за них» [5, с. 23-29]. Так, у ст. 49 I Женевської конвенції, ст. 50 II Женевської конвенції, ст. 129 III Женевської конвенції, ст. 146 IV Женевської конвенції міститься спільна для цих міжнародних договорів норма, яка передбачає, що «Кожна Висока Договірна Сторона зобов'язана розшукувати осіб, обвинувачуваних у тому, що вони вчинили або віддали наказ учинити такі серйозні порушення, та незалежно від іхнього громадянства віддавати їх до свого суду. Вона може також, якщо вважає це за доцільне, передавати їх згідно 3 положеннями свого законодавства для суду іншій заінтересованій Високій Договірній Стороні за умови, що ця Договірна Сторона зібрала достатньо серйозні докази для обвинувачення цих осіб».

Зазначені зобов'язання - вживати необхідних заходів для припинення порушень, передбачених Конвенціями, є складовою частиною більш загального зобов'язання, яке міститься у спільній для всіх Женевських конвенцій 1949 р. ст. 1, яке вимагає від держав «дотримуватися» i «змушувати дотримуватися» положень цих Конвенцій. У них встановлюється, що держави зобов'язані ввести в дію кримінальне законодавство, призначене для покарання осіб, винних у скоєнні серйозних порушень Конвенцій, тобто в скоєнні воєнних злочинів. Вони зобов'язані також розшукувати осіб, обвинувачених у скоєнні серйозних порушень, і передавати їх своєму суду або суду іншій державі.

Виходячи 3 аналізу положень Женевських конвенцій, можна скласти перелік воєнних злочинів, які відповідно до зобов'язань держав повинні заборонятися національним законодавством і за вчинення яких має передбачатися покарання. Важливість цього положення полягає в тому, що в більшості цивілізованих країн діє конституційний припис про пріоритет міжнародного права над внутрішньодержавним.

Отже, положення Женевських конвенцій та інших норм міжнародного права, що визначають злочинність порушень правил ведення збройних конфліктів, мають обов'язкову силу для національного правозастосування. Крім того, норми про злочинність зазначених у конвенціях порушень правил ведення війни повинні бути імплементовані у національне кримінальне законодавство держав-членів цих конвенцій, кількість яких станом на 2017 рік складає 196 держав. 3 іншого боку, міжнародне право не містить конкретних положень про класифікацію серйозних порушень, яка могла $б$ послужити підставою для їх систематизації. нормах вказуються лише ті види злочинів або правопорушень, які за своєю природою i ступенем жорстокості «не можуть залишитися безкарними з боку держав». 


\section{Міжнародне право}

Одними 3 найбільш вагомих джерел міжнародного права, що встановлюють злочинність порушень правил і звичаїв ведення воєнних дій, вважаються Додаткові протоколи I і II 1977 року до Женевських конвенцій 1949 року [2; 1]. При цьому посправжньому «революційне» значення має Додатковий протокол II, який встановив ряд злочинних порушень, скоєних у ході конфліктів неміжнародного характеру. Слід зазначити, що в Женевських конвенціях і Додатковому протоколі I перераховуються всі воєнні злочини, що згадуються в списках воєнних злочинів у раніше прийнятих документах, зокрема в тих, на підставі яких було укладено Аондонську угоду від 8 серпня 1945 року «Про судове переслідування i покарання головних військових злочинців європейських країн «осі».

Женевськими конвенціями 1949 р. визначаються наступні серйозні порушення правил i звичаїв ведення воєнних дій: навмисне вбивство; тортури і нелюдське поводження; біологічні експерименти; навмисне заподіяння тяжких страждань; заподіяння серйозного каліцтва або нанесення шкоди здоров'ю (ст. 50 I Женевської конвенції, ст. 51 II Женевської конвенції, ст. 130 III Женевської конвенції, ст. 147 IV Женевської конвенції); незаконне, довільне і широкомасштабне руйнування і привласнення майна, що не викликані воєнною необхідністю (ст. 50 I Женевської конвенції, ст. 51 II Женевської конвенції, ст. 147 IV Женевської конвенції); примушування військовополоненого до служби в збройних силах ворожої держави (ст. 130 III Женевської конвенції); позбавлення військовополоненого прав на справедливе та належне судове розслідування, передбачене Конвенціями (ст. 130 III Женевської конвенції, ст. 147 IV Женевської конвенції); незаконна депортація або переміщення особи; незаконний арешт особи; взяття заручників iз числа цивільного населення (ст. 147 IV Женевської конвенції). До серйозних порушень правил і звичаїв ведення війни, що визначаються у Додатковому протоколі I, відноситься нанесення збитку, шляхом будь-якої навмисної і невиправданої дії або бездіяльності, фізичному або психічному стану здоров'я і недоторканності осіб, що перебувають під владою супротивної сторони або інтернованих, затриманих чи будь-яким іншим чином позбавлених свободи в результаті збройного конфлікту. Зокрема, йдеться про: нанесення фізичних каліцтв, проведення медичних або наукових експериментів, видалення тканин або органів для пересадки, а також будь-яка інша медична процедура, яка не вимагається за станом здоров'я зазначеної особи і не відповідає загальноприйнятим медичним нормам, застосовуваним при аналогічних 3 медичної точки зору обставин до громадян сторони, що проводить цю процедуру, які не позбавлені волі в будь-якій формі (ст. 11 Додаткового протоколу I).

До серйозних порушень відносяться також дії, що здійснюються навмисно і 6 причиною смерті або тілесного ушкодження чи шкоди здоров'ю (п. 3 ст. 85 Додаткового протоколу I), які полягають у: перетворенні цивільного населення або окремих цивільних осіб на об'єкт нападу; вчиненні нападу невибіркового характеру, що зачіпають цивільне населення або цивільні об'єкти, коли відомо, що такий напад стане причиною надмірних втрат життя, поранень серед цивільного населення або завдасть шкоди цивільним об'єктам; вчиненні нападу на установки або споруди, що містять небезпечні речовини, коли відомо, що такий напад стане причиною надмірних втрат життя, поранень серед цивільного населення або завдасть шкоди цивільним об'єктам; перетворенні необоронних місцевостей і нейтральних зон на об'єкт нападу; вчиненні нападу на особу, коли відомо, що вона припинила брати участь у воєнних діях; віроломному використання розпізнавальної емблеми Червоного Хреста, Червоного Півмісяця, Червоного Кристала або інших захисних знаків.

До серйозних порушень відносяться також наступні дії, якщо вони вчинені умисно і в порушення Конвенцій і Протоколу I (п. 4 ст. 85 Додаткового протоколу I): переміщення окупуючою державою частини іiі власного цивільного населення на окуповану нею територію або депортація 
чи переміщення всього або частини населення окупованої території у межах цієї території чи за ії межі; невиправдана затримка репатріації військовополонених або цивільних осіб; застосування практики апартеїду, інших негуманних i принижуючих дій, заснованих на расовій дискримінації, які зневажають гідність особи; перетворення ясно розпізнаних історичних пам'яток, творів мистецтва або місць відправлення культу, які є культурною або духовною спадщиною народів і яким надається особливий захист, на об'єкт нападу, у результаті чого вони зазнають великих руйнувань, коли такі об'єкти не знаходяться в безпосередній близькості від військових об'єктів і не використовуються іншою стороною для підтримки збройних дій; позбавлення особи, яка користується захистом Конвенцій і Протоколу I, права на неупереджене і належне судочинство.

у Додатковому протоколі II, який поширюює сферу дії Женевських конвенцій на збройні конфлікти неміжнародного характеру, серйозними порушеннями правил ведення таких конфліктів, крім загальних приписів спільної для чотирьох Женевських конвенцій ст. 3, названі такі (ст. 13-18 Додаткового протоколу II): акти насильства або погрози насильством, що мають основною метою тероризувати цивільне населення; використання голоду серед цивільного населення як методу ведення військових дій; напад, знищення, вивезення або приведення в непридатність об'єктів, необхідних для виживання цивільного населення; напад на установки і споруди, що містять небезпечні речовини; вчинення будь-яких ворожих актів, спрямованих проти тих історичних пам'яток, творів мистецтва або місць відправлення культу, які є культурною або духовною спадщиною народу; переміщення цивільного населення з причин, пов'язаних зі збройним конфліктом.

Крім того, правила («закони і звичаї») ведення збройних конфліктів встановлені в інших міжнародно-правових актах, прийнятих у другій половині ХХ ст. До їх числа можна віднести такі міжнародні договори: Гаазька конвенція про захист культурних цінностей у випадку збройного конфлікту від 14 травня 1954 року [13]; Конвенція про заборону військового або будь-якого іншого ворожого використання засобів впливу на природне середовище від 18 травня 1977 року [11]; Конвенція про заборону або обмеження застосування конкретних видів звичайної зброї, які можуть вважатися такими, що завдають надмірних ушкоджень або мають невибіркову дію від 10 жовтня 1981 року [10]; Конвенція про заборону розробки, виробництва та накопичення запасів бактеріологічної (біологічної) і токсичної зброї та про їх знищення від 10 квітня 1972 року [12] та ін.

Як уже вище зазначалось, особливе місце серед джерел міжнародного кримінального права, посідають акти Міжнародних трибуналів ad hoc: МКТКЮ, МКТР, результати діяльності яких спричинили радикальні зміни і сприяли подальшому розвитку як міжнародного права в цілому, так i міжнародного кримінального права зокрема. Не можна не погодитися 3 оцінкою А. Нейєра щодо діяльності названих трибуналів: у зв'язку зі змінами в цій галузі тепер допускається міжнародне переслідування тих, хто скоїв злочини в ході внутрішніх збройних конфліктів, настільки поширених у наші дні. У перспективі, можливо, «національні суди багатьох країн відповідно до принципу універсальної підсудності судитимуть, обвинувачуватимуть і каратимуть відповідальних за такі злочини незалежно від того, де вони були здійснені. Дотепер лише кілька подібних справ було порушено в окремих державах, але 3 усвідомленням змін, що відбуваються в міжнародному праві, і в міру активізації правозахисних груп число таких процесів може істотно зрости» [27, р. 102].

Найважливішою подією, пов'язаною 3 формуванням джерельної бази міжнародного права щодо встановленням відповідальності за вчинення воєнних злочинів, стало прийняття 17 липня 1998 року Римського Статуту Міжнародного кримінального суду [22] (далі - Римський Статут МКС), який набув чинності 1 липня 2002 року. У цьому документі 


\section{Міжнародне право}

сформульовано поняття «воєнні злочини» (ст. 8), встановлено їх перелік, визначено межі застосування допустимого права, загальні принципи здійснення міжнародної та національної юрисдикції (зокрема, й при скоєнні воєнних злочинів), а також принципи міжнародного кримінального права. Однак більша частина положень Римського Статуту присвячена процедурним питанням і питанням судоустрою. Головне ж полягає в тому, що в цьому документі кінця XX ст. вперше оформлена цілісна система воєнних злочинів 3 міжнародного права. Так, до воєнних злочинів (ст. 8 Римського Статуту) відносяться серйозні порушення Женевських конвенцій 1949 року і інші серйозні порушення, перелічені у Статуті, вчинені у великих масштабах під час міжнародних i неміжнародних збройних конфліктів. На Римській дипломатичній конференції, присвяченій ухваленню Статуту, обговорювалося, що за останні півстоліття більшість серйозних порушень прав людини відбулося не в ході міжнародних збройних конфліктів, а в окремих державах. Тому в Статуті МКС включені сучасні стандарти МГП, які кваліфікують як кримінально карані воєнні злочини, серйозні порушення МГП, вчинені під час збройних конфліктів неміжнародного характеру, за винятком внутрішніх заворушень або безпорядків.

Визначення злочинів у Статуті 6 результатом тривалої і наполегливої роботи, яку проводили багато делегацій i їх експерти. Кожне 3 визначень чітко сформульовано, відображає чинні норми міжнародного права i відповідає вимозі визначеності у кримінальному праві. Судді Суду повинні строго тлумачити визначення i не застосовувати їх за аналогією. Мета Статуту полягає у встановленні об'єктивних міжнародних стандартів, що не залишають місця для довільних рішень. у спірних випадках ці визначення мають тлумачитися на користь підозрюваного чи обвинуваченого.

Таким чином, наразі основними джерелами, що регламентують порядок ведення збройного конфлікту, є Женевські конвенції 1949 року і Додаткові протоколи до них, нормами яких обмежується вибір засобів і методів ведення не тільки міжнародних конфліктів, але і конфліктів неміжнародного характеру. Однак комплексне визначення воєнних злочинів як таких стало можливим і було дано тільки у Римському статуті МКС. Римський статут містить своєрідний «кодекс воєнних злочинів» за міжнародним кримінальним правом.

\section{Висновки та пропозиції}

Таким чином, існують різні визначення воєнних злочинів, що відносяться до різних систем покарань на внутрішньодержавному та міжнародному рівнях. Після Другої світової війни ці злочини були чітко закріплені на міжнародному рівні в статутах міжнародних воєнних трибуналів, створених союзниками в Нюрнберзі і Токіо, у Женевських конвенціях 1949 року і в Додаткових протоколах 1977 року (як серйозні порушення Женевських конвенцій), а також в 1993 i 1994 роках у статутах МКТКЮ та МКТР. Наразі найповніший перелік злочинів, які підлягають покаранню міжнародним судовим органом, наводиться в Римському статуті МКС. МКС відіграє провідну роль в узгодженні визначень злочинів на національному та міжнародному рівнях. Україна підписала, але й дотепер не ратифікувала Римський статут. У цьому контексті варто зазначити, що зобов'язання України ратифікувати Римський статут МКС випливає із тексту Угоди про асоціацію між Україною, 3 одного боку, та Свропейським Союзом, Европейським співтовариством 3 атомної енергії і їхніми державами-членами, з іншого боку від 27.06.2014 року [24] (стаття 8). На необхідності прискорення ратифікації Україною Римського статуту наголошують також представники Европейського Союзу [20], Ради Европи та інших авторитетних міжнародних організацій. На нашу думку, Україна має виконати взяте перед EC міжнародно-правовое зобов'язання, але перед цим необхідно привести чинне законодавство, насамперед, кримінальне та кримінально-процесуальне, у відповідність до норм Римського статуту МКС, у тому числі щодо складу воєнних злочинів. 


\section{Мітература}

1. Додатковий протокол до Женевських конвенцій від 12 серпня 1949 року, що стосується захисту жертв збройних конфліктів неміжнародного характеру (Протокол II), від 8 червня 1977 року URL: http:// zakon.rada.gov.ua/laws/show/995_200 (дата звернення: 26.11.2018)

2. Додатковий протокол до Женевських конвенцій від 12 серпня 1949 року, що стосується захисту жертв міжнародних збройних конфліктів (Протокол I), від 8 червня 1977 p. URL: http://zakon.rada. gov.ua/laws/show/995_199 (дата звернення: 26.11.2018)

3. Женевська конвенція про поводження 3 військовополоненими від 12.08.1949 p. URL: http://zakon.rada.gov. ua/laws/show/995_153 (дата звернення: 25.11.2018)

4. Зелинская Н. А. Политические преступления в системе международной преступности / Н. А. Зелинская ; Одес. нац. юрид. академия. Одесса : Фенікс, 2003. 400 с.

5. Калугин В.Ю. Обязательства Республики Беларусь по пресечению серьезных нарушений международного гуманитарного права и их реализация в уголовном законодательстве / Виталий Юрьевич Калугин. Белорусский журнал международного права и международных отношений. 1998. № 3. С. 23-29. URL: http:// evolutio.info/content/view/159/49/ (дата звернення: 25.11.2018)

6. Конвенція про заборону розробки, виробництва, накопичення і застосування хімічної зброї та про ії знищення від 13 січня 1993 року URL: http://zakon.rada.gov.ua/laws/ show/995_182 (дата звернення: 26.11.2018)

7. Конвенція про заборону застосування, накопичення запасів, виробництва і передачі протипіхотних мін та про їх знищення від 18 вересня 1997 року. URL: http://zakon.rada.gov.ua/laws/ show/995_379 (дата звернення: 24.11.2018)

8. Конвенція про маркування пластичних вибухових речовин 3 метою їх виявлення від 1 березня 1991 року URL: http://zakon.rada.gov.ua/laws/show/995_016 (дата звернення: 24.11.2018)
9. Каюмова

A.P.

Смешаные (гибридные) уголовные трибуналы и интернационализированные суды в системе международной уголовной юстиции /А.Р. Каюмова. Казань, 2008. С. 40-41.

10. Конвенція про заборону або обмеження застосування конкретних видів звичайної зброї, які можуть вважатися такими, що завдають надмірних ушкоджень або мають невибіркову дію від 10 жовтня 1981 року URL: http://zakon.rada. gov.ua/laws/show/995_266 (дата звернення: 24.11.2018)

11. Конвенція про заборону військового або будь-якого ворожого використання засобів впливу на природне середовище ООН від 18.05.1977 p. URL: http://zakon.rada. gov.ua/laws/show/995_258 (дата звернення: 26.11.2018)

12. Конвенція про заборону розробки, виробництва та накопичення запасів бактеріологічної (біологічної) і токсинної зброї та про їх знищення від 10.04.1972 URL: http:// zakon.rada.gov.ua/laws/show/995_054 (дата звернення: 27.11.2018)

13. Конвенція про захист культурних цінностей у випадку збройного конфлікту від 14.05.1954 р. URL: http://zakon.rada. gov.ua/laws/show/995_157 (дата звернення: 27.11.2018)

14. Конвенція про захист цивільного населення під час війни від 12.08.1949 р. URL: http://zakon.rada.gov.ua/laws/show/995_154 (дата звернення: 27.11.2018)

15. Конвенція про поліпшення долі поранених і хворих у діючих арміях від 12.08.1949 p. URL: http://zakon.rada.gov. ua/laws/show/995_151 (дата звернення: 27.11.2018)

16. Конвенція про поліпшення долі поранених, хворих та осіб, які зазнали корабельної аварії, зі складу збройних сил на морі від 12.08.1949 р. URL: http://zakon.rada. gov.ua/laws/show/995_152 (дата звернення: 27.11.2018)

17. Міжнародна конвенція про боротьбу 3 вербуванням, використанням, фінансуванням і навчанням найманців від 4 грудня 1989 року URL: http://zakon.rada. gov.ua/laws/show/995_103 (дата звернення: 24.11.2018) 


\section{Мгородне право}

18. Нюрнбергский процесс: право против войны и фашизма /Под ред. А.И. Ледях, И.И. Аукашука. Ин-т государства и права РАН, 1995. 262 с.

19. Обычное международное гуманитарное право. /Под редакцией Жана-Мари Хенкертса и Ауизы Досвальд-Бек. Т. I. «Нормы». Москва, МККК, 2006. URL: https://www.icrc.org/ru/doc/assets/files/other/ customary.pdf (дата звернення: 24.11.2018)

20. «Потім буде пізно»: в EG закликали Київ терміново ратифікувати Римський статут URL: https:/ukr.segodnya.ua/politics/ potom-budet-pozdno-v-es-prizvali-kievsrochno-ratificirovat-rimskiy-statut-1 189506. html (дата звернення: 27.11.2018)

21. Репецький B.М., Лисик В.М. Поняття та ознаки воєнних злочинів / B.M. Репецький, В.М. Лисик. Альманах международного права. Вып. 1.2009. С. 120-125.

22. Римський статут міжнародного кримінального суду від 17.07.1998 р. URL: http://zakon.rada.gov.ua/laws/show/995_588 (дата звернення: 25.11.2018)

23. Статут Міжнародного військового трибуналу для суду та покарання головних військових злочинців європейських країн осі Ірландія, СРСР, США від 08.08.1945 р. URL: http://zakon.rada.gov.ua/laws/show/998_201 (дата звернення: 25.11.2018)

24. Угода про асоціацію між Україною, 3 однієї сторони, та Европейським Союзом, Европейським співтовариством 3 атомної енергї і їхніми державами-членами, 3 іншої сторони від 27.06.2014 року URL: http:// zakon.rada.gov.ua/laws/show/995_588 (дата звернення: 25.11.2018)

25. Doc. Preparatory Comission for the International Criminal Court /1999/WGEC/ INF. 1. $\$ 16-20$

26. Greek Case, 1969. URL: http://www. worldcat.org/title/greek-case-applicationno-332167-denmark-v-greece-applicationno-332267-norway-v-greece-application-no332367-sweden-v-greece-application-no-334467 -netherland s-v-greece-report-of-thecommission/oclc/63475293 (дата звернення: 25.11.2018)

27. Neier A. War Crimes: Brutality, Genocide, Terror, and the Struggle for Justice / Aryeh Neier. Times Books. 1998. 286 p.

28. Prosecutor V. Ante Furundzija. Case № IT-95-17/1-T. 10 December 1998.

29. Prosecutor V. Dusko Tadic. ICTY T. Ch. II. 11 November 1999.

30. Prosecutor v. Zejnil Delalic, Zdravko Mucic, Hazim Delic, Esad Landzo, Case № IT96-21-T. 16 November 1998.

31. Prosecutor V. Goran Jelisic. Case № IT95-10. 14 December 1999.

32. Prosecutor V. Tihomir Blaskic. Case № IT-95-14-T. Ch. II. 3 March 2000.

33. Prosecutor V. Zlatko Aleksovsky. ICTY T. Ch I. 25 June 1999.

34. Weizaecker \& Others. US M i l i t a r y Tribunal at Nurenberg, 14 April 1949. 